\title{
Bodytime and Burnout
}

\section{Konrad Kleiner}

University of Vienna, Centre of Sport Science and University Sports, Auf der Schmelz 6A, A-1150 Vienna, Austria

\section{Introduction}

The book "Bodytime.Leib und Zeit bei Burnout und in anderen Grenzerfahrungen", edited by Reinhold Esterbauer, Andrea Paletta, Philipp Schmidt und David Duncan published by Karl Alber is an outstanding collection of contributions with the topics body-and time-experience during burnout and further existential experiences.

The concepts of "body" and "time" embody phenomenons, which in modernism have become subjects of theoretical and practical discourse in various heterogenous scientific disciplines (philosophy, phenomenology, pedagogy, sports science, dance therapy, sociology) for therapeutic and prophylactic interventions on a disciplinary as well as inter- and transdisciplinary level [1,2]. The focus of interest lies on analysis models and experience dynamics of opposing and correlating 'proper times' for aesthetic forms of temporal complexity. Against this background, the respecting publication presents first results of the project „Bodytime - An interdisciplinary inquiry on regular body rhythm and its dysfunctions" in an appealing, substantially differentiated and linguistically sophisticated manner. Compiled on 352 pages, the volume comprises 16 papers divided into three sections: (a) "Bodily constitution of time", (b) "Time Dimensionality of Bodiliness" and (c) "Dysfunctional Time Dynamics and Burnout". The first section discusses the fundamental philosophical questions of body, time, experience and spaciality from a transzendental phenomenological perspective (e.g. Husserl [3], an existence- and body-phenomenological position (e.g. Heidegger), as well as from a position of practical philosophy (Schopenhauer, Levinas [4] Specific theoretical positions of selected authors are being addressed, examined, challenged and discussed in contrast to selected models.

The second section approaches questions of "Acceleration and Age as a Body-Time-Phenomenon", "Characteristics of Life Ages and Life Phases" (e.g. Viktor von Weizäcker [5] and "Biographical Reconstruction and Bodily Experience" (e.g. fatigue, exhaustion, time deprivation) ensuing from perspectives of various disciplines (e.g. sociology, naturalism, pedagogy [6]. The third section addresses dysfunctions of body time (e.g. burnout, deprivation of freedom) by introducing qualitative studies lead by Andrea Paletta, which are based on interviews, diary entries, motion-analytical diagnostic procedures and methods of dance therapy, investigating primarily individual timely experience (proper time, intersubjective time, drive) and burnout. The respective results are of particular importance with respect to strategies for burnout prophylaxis and therapy. To conclude, the volume at hand is theoretically and practically perfectly compatible with the current scientific discourse regarding the complex topic of "body time". Not only due to the fact that it reviews heterogenous theoretical positions, confronts them with one other and gives an outlook on necessary future research, but likewise due to the volume's variety of topics and perspectives, it is particularly recommendable.

\section{Competing Interests}

The authors declare that they have no competing interests.

\section{Publication History:}

Received: September 09, 2016

Accepted: January 31, 2017

Published: February 02, 2017

\section{Keywords:}

Time experience, Body rhythm, Burnout, Aging, Interdisciplinary

\section{References}

1. Geissler KA (2014) Alles hat seine Zeit, nur ich hab keine: Wege in eine neue Zeitkultur. München: Oekom Verlag

2. Hartung G (2015) Mensch und Zeit: Studien zur Interdisziplinären Anthropologie. Wiesbaden: Springer

3. Husserl, E (1952) Ideen zu einer reinen Phänomenologie und phänomenologischen Philosophie.2. Phänomenologische Untersuchungen zur Konstitution, M. Biemel (Ed) Haag: Nijhoff

4. Schopenhauer,A (1968) Die Welt als Wille und Vorstellung. W.Frhr. von Löhneysen (Ed) Darmstadt: Wiss. Buchgesellschaft

5. Weizsäcker, V von (2005): Pathosophie. Gesammelte Schriften Bd.10 Frankfurt/M: Suhrkamp

6. Gerisch B (2013) „Von jagender Hast und vorzeitigem Zusammenbruch“ Zur Psychodynamik schleichender Veränderungen in beschleunigten Zeiten. In: Journal für Psychoanalyse 54: 7-28.
*Corresponding Author: Prof. Konrad Kleiner, Universität Wien, Centre of Sport Science and University Sports, Auf der Schmelz 6A, A-1150 Vienna, Austria; E-mail: konrad.kleiner@univie.ac.at

Citation: Kleiner K (2017) Bodytime and Burnout. Int J Phys Ther Rehab 3: 128 doi: https://doi.org/10.15344/2455-7498/2017/128

Copyright: () 2017 Kleiner et al. This is an open-access article distributed under the terms of the Creative Commons Attribution License, which permits unrestricted use, distribution, and reproduction in any medium, provided the original author and source are credited. 